\title{
A NEW APPROACH TO THE STUDY OF SIMILARITY STRUCTURE IN THE AREA OF GREEN GROWTH IN OECD COUNTRIES
}

\author{
Iwona Bak ${ }^{1}$, Associate Professor; Katarzyna Cheba ${ }^{2}$, Assistant Professor and Magdalena \\ Ziolo $^{3}$, Associate Professor \\ 1,2West Pomeranian University of Technology, Szczecin; ${ }^{3}$ University of Szczecin
}

\begin{abstract}
The aim of the study is an assessment of current level of development in the green growth area of the OECD countries. For this purpose, the seven main indicators characterized the green growth in 2004 and 2015 were utilized. To identify the relations between them, the multi-dimensional correspondence analysis with the complex matrix of markers was used. The main advantage of this method is possibility to implement division into groups of OECD countries taking into account the level of each of analysed indicators, not only a mean level of development in this area. In the paper, the OECD countries were separated into four groups with different level of development in the green growth area. The results of the study confirmed visible changes in the area of the green growth in 2004 and 2015 for the majority of countries. There are also visible changes between these years.
\end{abstract}

Key words: green growth, OECD countries, correspondence analysis.

JEL code: $\mathrm{C} 38, \mathrm{P} 11, \mathrm{P} 36$.

\section{Introduction}

In the literature the term of sustainable development has been defined in many ways, but the most known definition is from the Brundtland Report "Our Common Future" (WCED, 1987): "sustainable development is development that meets the needs of the present without compromising the ability of future generations to meet their own needs". According to many definitions presented in the literature (i.e. Dovers and Handmer, 2009; Borys, 2011), sustainable development concerns three main areas: economic growth, social protection and protection of the environmental quality. Each of them reinforces the others and the development consistent with this idea has to include regulations related to every of them. According to the strong rule of the durability of development, which is the one of the most important rules of sustainable development, replacing the loss of one resource with the other can only take place within individual areas. It is true, but in this way each of these areas should be considered separately. Meanwhile, in many cases it is difficult to determine the boundaries especially between economic and environmental dimension. Some process can describe both of them. The emission of $\mathrm{CO}_{2}$ may be treated as an impact of economy on the environment and also as an indicator describing changes in the environment. Hence in the last research related to the sustainable development the new connections between this concept and others was proposed. One of them, relatively new is defined as green growth or green economy. According to OECD (The Organisation for Economic Co-operation and Development) green growth means „fostering economic growth and development while ensuring that natural assets continue to provide the resources and environmental services on which our well-being relies" (Green growth..., 2016). While the green economy is defined by UNEP (United National Environment Programme) as: „an economy that aims at reducing environmental risks and ecological scarcities, and that aims for sustainable development without degrading the environment, (Lynn and Eda, 2014). It is worth to indicate, the green growth or the green economy is not a replacement for sustainable development. The main purpose of them is to provide more precise approach to achieve progress across economic and environmental areas of sustainable development. A development in the area of the green growth

\footnotetext{
1 iwona.bak@zut.edu.pl

2 katarzyna.cheba@zut.edu.pl

3 Magdalena.Ziolo@usz.edu.pl
} 
is particularly evident in the case of more developed economies, more interested in changes which do not degrade the environment.

In this context the aim of the study is an assessment of current level of development in the green growth area of the OECD countries. The article attempts to answer the question: what was the state of the green economy in OECD countries in relation to the average level of selected variables characterizing this economy in 2004 and 2015. The paper is divided into 5 sections. The first presents the aim of the research. Next, the statistical data is presented. The third one is dedicated to a presentation of the mathematical research method. The fourth section presents the research results and discussion, and the last one contains conclusions. The added value of the paper is a division into groups of OECD countries according their level of development in the green growth area based on the proposed method. The method applied for this purpose let separate the OECD countries taking into account a level of each analysed indicators, not only a mean level of development in this area.

\section{Statistical materials}

The analyses presented in the paper utilize information on the main indicators applied to assessing the level of development of the green growth. The OECD countries are the objects of the study. In the OECD (2018) database seven following indicators are utilized for this purpose:

$X_{1}$ - production-based $\mathrm{CO}_{2}$ intensity, energy-related $\mathrm{CO}_{2}$ per capita, tonnes,

$X_{2}$ - demand-based $\mathrm{CO}_{2}$ intensity, energy-related $\mathrm{CO} 2$ per capita, tonnes,

$X_{3}$ - non-energy material productivity, GDP per unit of DMC, US dollars per kilogram,

$X_{4}$ - environmentally adjusted multifactor productivity growth, \%,

$X_{5}-$ loss of natural and semi-natural vegetated land, \%,

$X_{6}$ - gain of natural and semi-natural vegetated land, \%,

$X_{7}$ - mean population exposure to PM2.5, micrograms per cubic metre.

In the paper the changes of these indicators in two years: 2004 (before economic crisis) and 2015 (last available data) were compared. The objective of the comparison of the results was to show which countries are in a positive and negative contrast to the average level of selected indicators and what are the links between countries from the point of view of these diagnostic features. Every indicator was characterized by a very large diversification (even over $100 \%, X_{4}$ in 2015) and strong asymmetry (the highest in the case of $X_{3}$ in 2004 and $X_{4}$ in 2015), (Table 1).

Table 1

\section{Descriptive statistics characterizing the distribution of the indicators}

\begin{tabular}{|c|c|c|c|c|c|c|c|c|}
\hline \multirow{2}{*}{ Var. } & \multicolumn{3}{|c|}{2004} & \multicolumn{4}{c|}{2015} \\
\cline { 2 - 9 } & Mean & Median & Vs (\%) & Asymmetry & Mean & Median & Vs (\%) & Asymmetry \\
\hline$X_{1}$ & 9.096 & 8.118 & 50.905 & 1.496 & 7.463 & 6.560 & 47.583 & 1.221 \\
\hline$X_{2}$ & 10.549 & 10.952 & 39.104 & 0.641 & 9.583 & 9.114 & 39.086 & 0.991 \\
\hline$X_{3}$ & 2.812 & 2.009 & 94.953 & 4.135 & 3.133 & 2.649 & 52.689 & 1.049 \\
\hline$X_{4}$ & 2.489 & 2.549 & 58.742 & 0.371 & -0.010 & 0.165 & over 100 & -3.839 \\
\hline$X_{5}$ & 2.990 & 2.769 & 70.267 & 1.532 & 3.916 & 3.033 & 77.265 & 2.113 \\
\hline$X_{6}$ & 2.250 & 1.432 & 94.394 & 1.256 & 3.112 & 2.177 & 87.174 & 1.120 \\
\hline$X_{7}$ & 12.812 & 13.559 & 37.093 & 0.063 & 13.700 & 12.998 & 47.199 & 0.556 \\
\hline
\end{tabular}

Source: author's calculations based on the OECD data, where Var. is variable, Vs is coefficient of variation

In the set of diagnostic features there are indicators, the higher values of which reflect the better of the green growth (stimulants) and those, the level of which is desired to be lower (destimulants) 
(Nowak, 1990). The majority of indicators adopted for the study are destimulants. Only three were regarded as stimulants $\left(X_{3}, X_{4}, X_{6}\right)$.

\section{Description of the research methods}

In the article the multi-dimensional correspondence analysis with the complex matrix of markers ${ }^{1}$ was used. Problems related to the correspondence analysis of variables in the Burt's matrix are discussed in detail, inter alia, in Greenacre's (1984, 1993), Andersen's (1991), Lebart's et al. (1984), Clausen's (1998) papers. The procedure was carried out in the following stages (Stanimir, 2005):

1) preparing the complex matrix of markers,

2) determining the dimension of the real coexistence space based on the formula:

$$
K=\sum_{q=1}^{Q}\left(J_{q}-1\right)
$$

where: $J_{q}$ - the number of categories of the variable $\mathrm{q}(\mathrm{q}=1,2, \ldots, Q), Q$ - the number of variables.

3 ) checking to which extent eigenvalues (main inertias) of the lower dimension space explain total inertia $(\lambda)$; for this purpose the Greenacre's criterion was used, according to which main inertias larger than the inverse of the number of analysed variables are regarded as important for the study (1/Q). Total inertia is the $K$ total of eigenvalues where $K$ is the dimension of genuine coexistence space.

4) improving the quality of representation through the modification of eigenvalues according to Greenacre's proposal (Greenecre, 1984):

$$
\tilde{\lambda}_{k}=\left(\frac{Q}{Q-1}\right)^{2} \cdot\left(\sqrt{\lambda_{B, k}}-\frac{1}{Q}\right)^{2}
$$

where: $Q$ - the number of analysed variables, $\lambda-k$ eigenvalue $(k=1,2, \ldots, k)$,

$5)$ graphic presentation of results with the use of classification methods.

If the space with the dimension larger than three is the best form of the presentation of variables' coexistence, another method of analysing the results should be selected. For this purpose, one can use classification methods in the space of both low and high dimension. The categories of all analysed features should be determined as objects, while values of coordinates of projecting each category constitute variables. The number of variables depends on the dimension of the selected projection space. When the projection space is five-dimensional in the analysis five variables are used, i.e. coordinates of five axes creating that space (Bak, 2013). For this purpose, the new values of coordinates have to be determined by means of the formula:

$$
\tilde{F}=F^{*} \cdot \Gamma^{-1} \cdot \tilde{\Lambda}
$$

where: $\tilde{F}$ - matrix of modified values of coordinates for the category of examined variables with the $K \times k$ dimension, $F^{*}$ - matrix of original values of coordinates for the category of examined variables with the $K \times k$ dimension, $\Gamma^{-1}$ - diagonal inverse matrix of specific values $(\gamma k$ with the $k \times k$ dimension, $\gamma_{k}-k$ specific value which is the square root of the $k$ eigenvalue $\left(\lambda_{k}\right), \tilde{\Lambda}-$ diagonal 
matrix of modified eigenvalues with the $k \times k$ dimension, $k$ - dimension of the genuine coexistence space.

\section{Research results and discussion}

The correspondence analysis was carried out by stages described in the previous chapter. The set of diagnostic features, apart from seven zero-one variables, included the names of 36 OECD countries. Due to this fact the dimension of the genuine coexistence space amounted to 42 (formula 1 ). Next, the extent to which eigenvalues with a lower dimension explain total inertia $\left(\lambda_{2004}=5.2501\right.$; $\left.\lambda_{2015}=5.2506\right)$ was checked. In accordance with the Greenacre's criterion, main inertias larger than $\frac{1}{Q}=\frac{1}{Q_{2004}}=\frac{1}{Q_{2015}}=\frac{1}{8}=0,125$ were regarded as important for the study. It results from Tables 2-3 that in two of examined years are inertias for $\mathrm{K}$ taking values to and including $9^{1}$.

Table 2

The results of correspondence analysis in 2004

\begin{tabular}{|c|c|c|c|c|c|c|c|}
\hline $\mathbf{k}$ & $\begin{array}{c}\text { Eigen- } \\
\text { values } \gamma_{k}\end{array}$ & $\begin{array}{c}\text { Singular- } \\
\text { values } \lambda_{k}\end{array}$ & $\lambda_{k} / \lambda$ & $\tau_{k}$ & $\tilde{\lambda}_{k}$ & $\tilde{\lambda}_{k} / \tilde{\lambda}$ & $\tilde{\tau}_{k}$ \\
\hline 1 & 0,6031 & 0.3638 & 6.9291 & 6.9291 & 0.2986 & 0.2083 & 0.2083 \\
\hline 2 & 0.5794 & 0.3358 & 6.3951 & 13.3242 & 0.2697 & 0.1881 & 0.3964 \\
\hline 3 & 0.5082 & 0.2583 & 4.9199 & 18.2442 & 0.1918 & 0.1338 & 0.5302 \\
\hline 4 & 0.4820 & 0.2323 & 4.4245 & 22.6687 & 0.1664 & 0.1161 & 0.6463 \\
\hline 5 & 0.4676 & 0.2186 & 4.1640 & 26.8327 & 0.1533 & 0.1069 & 0.7532 \\
\hline 6 & 0.4372 & 0.1911 & 3.6399 & 30.4726 & 0.1273 & 0.0888 & 0.8420 \\
\hline 7 & 0.3875 & 0.1501 & 2.8599 & 33.3325 & 0.0900 & 0.0628 & 0.9048 \\
\hline 8 & 0.3537 & 0.1251 & 2.3826 & 35.7150 & 0.0683 & 0.0476 & 0.9524 \\
\hline 9 & 0.3536 & 0.1250 & 2.3811 & 38.0961 & 0.0682 & 0.0476 & 1.0000 \\
\hline
\end{tabular}

Source: author's calculations with usage of STATISTICA $12 . \overline{0}$

Table 3

The results of correspondence analysis in 2015

\begin{tabular}{|c|c|c|c|c|c|c|c|}
\hline $\mathbf{k}$ & $\begin{array}{c}\text { Eigen- } \\
\text { values } \gamma_{k}\end{array}$ & $\begin{array}{c}\text { Singular- } \\
\text { values } \lambda_{k}\end{array}$ & $\lambda_{k} / \lambda$ & $\tau_{k}$ & $\tilde{\lambda}_{k}$ & $\tilde{\lambda}_{k} / \tilde{\lambda}$ & $\tilde{\tau}_{k}$ \\
\hline 1 & 0.6031 & 0.3638 & 6.9284 & 6.9284 & 0.2986 & 0.2082 & 0.2082 \\
\hline 2 & 0.5794 & 0.3358 & 6.3946 & 13.3230 & 0.2697 & 0.1881 & 0.3963 \\
\hline 3 & 0.5082 & 0.2583 & 4.9195 & 18.2425 & 0.1918 & 0.1338 & 0.5301 \\
\hline 4 & 0.4820 & 0.2323 & 4.4241 & 22.6666 & 0.1664 & 0.1161 & 0.6461 \\
\hline 5 & 0.4676 & 0.2186 & 4.1636 & 26.8302 & 0.1533 & 0.1069 & 0.7530 \\
\hline 6 & 0.4372 & 0.1911 & 3.6396 & 30.4698 & 0.1273 & 0.0887 & 0.8417 \\
\hline 7 & 0.3875 & 0.1501 & 2.8596 & 33.3294 & 0.0900 & 0.0628 & 0.9045 \\
\hline 8 & 0.3544 & 0.1256 & 2.3924 & 35.7218 & 0.0687 & 0.0479 & 0.9524 \\
\hline 9 & 0.3536 & 0.1250 & 2.3807 & 38.1025 & 0.0682 & 0.0476 & 1.0000 \\
\hline
\end{tabular}

Source: author's calculations with usage of STATISTICA $12 . \overline{0}$

For these dimensions values of the measure $\tau_{\mathrm{k}^{2}}$ were analysed and it turned out that the level of explanation of inertias in three-dimensional space, both in 2004 and 2015, amounts to $18.24 \%$ In order to improve the quality of representation in the three-dimensional space the modification of eigenvalues according to formula (2) was carried out. As a result of conducted modification the level

\footnotetext{
1 In Tables 2-3 results for $K \geq 9$ were ignored because for these dimensions main inertias did not exceed 0.125 . ${ }^{2}$ This measure determines the inertia share of a selected dimension $\left(\lambda_{k}\right)$ in the total inertia $(\lambda)$.
} 
of total inertia explanation significantly increased. The first three eigenvalues constitute $53.02 \%$ of the modified total inertia in 2004 and in $50.31 \%$ in 2015.

Due to a large number of analysed variables and their variants, the interpretation of results obtained in the three-dimensional space is very hard. In order to achieve clearer interpretation of results the Ward's method was applied which enabled identification of connections between variants of variables. Ward's method is one of agglomeration methods of grouping. It is used in empirical studies both in reference to classification of objects and variables. In this method the distance between groups is defined as the difference module between totals of squares of points' distances to centres of groups to which these points belong (Pociecha et al. 1988; Gatnar and Walesiak, 2004; Malina, 2004; Balicki, 2009). New values of coefficients in the three-dimensional space for categories of variables were determined with the use of formula (3). Results of segmentation of OECD countries were presented in Table 4 and 5.

Table 4

\section{Characteristics of the green growth in OECD countries in 2004}

\begin{tabular}{|c|c|c|}
\hline Group & Countries & Characteristics \\
\hline I & $\begin{array}{l}\text { Australia, Canada, } \\
\text { Estonia, Finland, Iceland, } \\
\text { Ireland, Latvia, Norway, } \\
\text { Sweden, the United } \\
\text { States }\end{array}$ & $\begin{array}{l}\text { In these countries, the loss of natural and semi-natural vegetation areas and } \\
\text { the level of PM } 2.5 \text { concentration to which a resident of the country is exposed } \\
\text { throughout the year are smaller (positive assessment). The profit from natural } \\
\text { and semi-natural areas covered with vegetation was assessed negatively. }\end{array}$ \\
\hline II & $\begin{array}{l}\text { Chile, France, Hungary, } \\
\text { Lithuania, Mexico, New } \\
\text { Zealand, Poland, } \\
\text { Portugal, Slovak Republic, } \\
\text { Slovenia, Spain }\end{array}$ & $\begin{array}{l}\text { Countries in this group were rated positively due to the level of } \mathrm{CO} 2 \text { emissions } \\
\text { from the coal burning, oil, natural gas and other fuels, as well as } \mathrm{CO} 2 \text { emissions } \\
\text { from energy emitted at various stages of production of goods and services } \\
\text { consumed in the domestic final demand. The relation of GDP to the domestic } \\
\text { consumption of materials was negatively assessed, which means a faster } \\
\text { increase in the consumption of raw materials than GDP. }\end{array}$ \\
\hline III & $\begin{array}{l}\text { Austria, Israel, Italy, } \\
\text { Korea, the Netherlands, } \\
\text { Switzerland, Turkey }\end{array}$ & $\begin{array}{l}\text { Countries in this group deserve a negative rating because of: efficiency at the } \\
\text { macroeconomic level (national) including, e.g., technological changes, } \\
\text { institutional and organizational improvements, as well as loss of natural and } \\
\text { semi-natural vegetation areas and the level of PM } 2.5 \text { concentration to which a } \\
\text { resident of the country is exposed throughout the all year. Only profit from } \\
\text { natural and semi-natural areas covered with vegetation was positively } \\
\text { assessed. }\end{array}$ \\
\hline IV & $\begin{array}{l}\text { Belgium, the Czech } \\
\text { Republic, Denmark, } \\
\text { Germany, Japan, } \\
\text { Luxembourg, the United } \\
\text { Kingdom }\end{array}$ & $\begin{array}{l}\text { These countries were assessed positively due to the relation of GDP to the } \\
\text { domestic consumption of materials, which means a slower increase in the } \\
\text { consumption of raw materials than GDP, and due to productivity at the } \\
\text { macroeconomic level including, technological changes, institutional and } \\
\text { organizational improvements. The negative assessment was given to the level } \\
\text { of CO2 emissions from the coal burning, crude oil, natural gas and other fuels, } \\
\text { as well as CO2 emissions from energy emitted at various stages of production } \\
\text { of goods and services consumed in the domestic final demand. }\end{array}$ \\
\hline
\end{tabular}

Source: author's calculations

The results of the research confirmed an existence of significant differences of development in the area of green growth in the OECD countries. This is related to their general socio-economic development, the level of industrialization, the development of agriculture, the degree of urbanization, etc. This diversification is also visible in other area related to the sustainable development in this group of countries. The problem of inequality of socio-economic development in OECD countries was also noticed in the report "Regional development policies in OECD countries" published in 2010 (OECD, 2010). The authors of this report indicated that in most countries, socioeconomic disparities persist, though there are differences in intensity and in how these problems are perceived. In some countries as: Austria, Denmark, Luxembourg and the Netherlands, disparities are considered to be relatively limited. In others: Germany, Italy, Finland, Japan, the Czech Republic and Hungary, severe inter-regional disparities remain or are even increasing. T. Van de Rheede (2014) indicated that inequality has negative implications for the environment and social and 
economic implications. According to this author inequality implies biodiversity losses. Inequalities are also observed in the case of sustainable development of European Union countries. Problem of inequality in every dimension of sustainable development was indicated in many papers (i.e. Brown et al., 1987; Hopwood et al., 2005; Bak and Cheba, 2018).

Table 5

\section{Characteristics of the green growth in OECD countries in 2015}

\begin{tabular}{|c|c|c|}
\hline Group & Countries & Characteristics \\
\hline I & $\begin{array}{l}\text { Chile, France, Hungary, } \\
\text { Latvia, Lithuania, Mexico, } \\
\text { New Zealand, Poland, } \\
\text { Portugal, Slovak Republic, } \\
\text { Slovenia, Spain, Sweden }\end{array}$ & $\begin{array}{l}\text { Countries in this group were rated positively due to the level of } \mathrm{CO} 2 \text { emissions } \\
\text { from the coal burning, oil, natural gas and other fuels, as well as } \mathrm{CO} 2 \text { emissions } \\
\text { from energy emitted at various stages of production of goods and services } \\
\text { consumed in the domestic final demand. The relation of GDP to the domestic } \\
\text { consumption of materials was negatively assessed, which means a faster } \\
\text { increase in the consumption of raw materials than GDP. }\end{array}$ \\
\hline II & $\begin{array}{l}\text { Austria, Belgium, the } \\
\text { Czech Republic, Denmark, } \\
\text { Germany, Greece, Israel, } \\
\text { Italy, Japan, Korea, } \\
\text { Luxembourg, the } \\
\text { Netherlands, Switzerland, } \\
\text { Turkey }\end{array}$ & $\begin{array}{l}\text { Countries in this group deserve a negative rating because of: efficiency at the } \\
\text { macroeconomic level (national) including, e.g., technological changes, } \\
\text { institutional and organizational improvements, as well as loss of natural and } \\
\text { semi-natural vegetation areas and the level of PM } 2.5 \text { concentration to which a } \\
\text { resident of the country is exposed throughout the all year. Only profit from } \\
\text { natural and semi-natural areas covered with vegetation was positively } \\
\text { assessed. }\end{array}$ \\
\hline III & $\begin{array}{l}\text { Australia, Canada, } \\
\text { Estonia, Finland, Iceland, } \\
\text { Ireland, Norway, the } \\
\text { United States, the } \\
\text { United Kingdom, }\end{array}$ & $\begin{array}{l}\text { Countries in this group were assessed positively due to the four indicators: a) } \\
\text { the relation of GDP to the domestic consumption of materials, which means a } \\
\text { slower increase in the consumption of raw materials than GDP, b) efficiency at } \\
\text { the macroeconomic level (national) including, e.g., technological changes, } \\
\text { institutional and organizational improvements, as well as c) loss of natural and } \\
\text { semi-natural vegetation areas and d) the level of PM2.5 concentration to which } \\
\text { a resident of the country is exposed throughout the all year. } \\
\text { Negative rating applies to such indicators as: the level of CO2 emissions from } \\
\text { the coal burning, oil, natural gas and other fuels, as well as CO2 emissions from } \\
\text { energy emitted at various stages of production of goods and services consumed } \\
\text { in the domestic final demand and profit from natural and semi-natural areas } \\
\text { overgrown with vegetation. }\end{array}$ \\
\hline
\end{tabular}

Source: author's calculations

Because the green growth is closely linked to the sustainable development the same changes can be observed in both of them. Therefore, it is critical that environmental, economic and social policies are aligned towards integrated the green growth. It is worth indicating that despite the existing differences, it was not possible to point countries significantly different (in plus or in minus) from the mean values of all examined indicators in OECD countries. It means that the division into groups of better and worse OECD countries is not so simple. In 2004 countries assigned to the second and third groups are characterized by the same results as countries in the first and second group in 2015. The difference concerns only the number of OECD countries in the above-mentioned groups - in 2015 there were more of them.

The main purpose of the analyses related to the green growth is concretization of the sustainable development. Because of this, it is suiTable that the development in this area will correspond with the changes in sustainable development. The changes in these areas require support from legal and fiscal solutions dedicated to them. The green growth is also important area of the relatively new analyses related to the sustainable competitiveness, defined as: "the status and the directions of changes in the country's ability to compete in a sustainable way in the struggle for shares in broadly understood international trade conducted with the care for the environment and society" (Cheba, 2019). The basis for its description and definition is the current, still developing scientific acquis and practical achievements in the field of sustainable development and research focusing on competitiveness considered in relation to the national economy. In the second one the development in the area of the green growth is especially important. 


\section{Conclusions}

1) The results of the study confirmed visible changes in the area of the green growth in 2004 and 2015 for the majority of countries. The explanation of the reasons for these changes would require more detailed information, as: the level of commitment of countries to environmental protection and the analysis of their socio-economic situation.

2) Due to the importance of the problem related to the green growth and its impact on the improvement of human well-being, social justice as well as significant reduction of environmental degradation, it is necessary to conduct further research in this area. This means the need to collect and analyse statistical data on the green economy.

3) Reliable, properly selected and current data in this field is an important element of: environmental protection policies, the use of economic instruments or activities supporting ecological innovation and investments in green technologies and monitoring the effectiveness of these activities. These data can be used by public and private sector entities in decision making and presented in a broader context. They can enable monitoring of changes taking place in the environment, economy and society (US, 2017).

4) The changes in the area of the green growth require support from legal and fiscal solutions. In the literature, this area is defined as sustainable finance (Ziolo et al., 2016). Research into the relationship between green growth, sustainable development and sustainable finance is an important direction of further economic research and analysis.

\section{Acknowledgment}

Research results presented in this paper are an element of research project implemented by the National Science Centre Poland under the grant OPUS13 No UMO-2017/25/B/HS4/02172.

\section{Bibliography}

1. Andersen, E. B. (1991). The Statistical Analysis of Categorial Data. Springer-Verlang, Berlin.

2. Balicki, A. (2009). Statystyczna analiza wielowymiarowa i jej zastosowania spoleczno-ekonomiczne. Wydaw. Uniwersytetu Gdanskiego, Gdansk.

3. Bak, I. (2013). Statystyczna analiza aktywnosci turystycznej seniorow w Polsce. Wydawnictwo Uczelniane Zachodniopomorskiego Uniwersytetu Technologicznego w Szczecinie, Szczecin.

4. Bak, I., Cheba, K. (2018). The Application of the Dynamic Classifications in Order to Evaluate the Changes of the European Union's Sustainable Development. Proceedings of the 2018 International Conference "ECONOMIC SCIENCE FOR RURAL DEVELOPMENT", Jelgava.

5. Borys, T. (2011). Zrownowazony rozwoj - jak rozpoznac lad zintegrowany, (Sustainable development - how to recognize integrated order), Problemy Ekorozwoju: studia filozoficzno-socjologiczne, No. 6(2), pp. 75-81.

6. Brown, B., J., Hanson, M., E., Liverman, D., M., Merideth, R., W., Jr. (1987). Global Sustainability: Toward Definition, Environmental Management, No. 11(6), pp. 713-719.

7. Cheba, K. (2019). Zrownowazona konkurencyjnosc krajow Unii Europejskiej. Studia literaturowoempiryczne. CeDeWu, in press.

8. Dovers, S., R., Handmer, J., W. (2009). Contradictions in Sustainability. Environmental Conservation, 20(3), pp. 217-222.

9. Clausen, S. E. (1998). Applied Correspondence Analysis: An Introduction, Sage Publications, Thousand Oaks.

10. Green Growth Knowledge Platform (GGKP) (2016). Measuring Inclusive Green Growth at the Country Level. Seoul, Paris, Nairobi and Washington DC: Global Green Growth Institute, Organisation for Economic Cooperation and Development, United Nations Environment Programme and World Bank.

11. Greenacre, M. (1984). Theory and Applications of Correspondence Analysis. Academic Press, London.

12. Greenacre, M. (1993). Correspondence Analysis in Practice. Academic Press, London.

13. Hopwood, B., Mellor, M., O'Brien, G. (2005). Sustainable Development: Mapping Different Approaches, Sustainable Development, No. 13(1), pp. 38-52.

14. Lebart, L., Morineau, A., Warwick, K. M. (1984). Multivariate Descriptive Statistical Analysis. Correspondence Analysis and Related Techniques for Large Matrices. John Wiley \& Sons. Inc., New York.

15. Lynn R. Kahle, Eda Gurel-Atay, Eds (2014). Communicating Sustainability for the Green Economy. M.E. Sharpe. New York. 
16. Malina, A. (2004). Wielowymiarowa analiza przestrzennego zroznicowania struktury gospodarki Polski wedlug wojewodztw. Wydawnictwo AE w Krakowie, Krakow.

17. Gatnar, E., Walesiak, M. (eds.) (2004). Metody statystycznej analizy wielowymiarowej w badaniach marketingowych, Wydaw. AE we Wroclawiu, Wroclaw.

18. Nowak, E. (1990). Metody taksonomiczne w klasyfikacji obiektów społeczno-gospodarczych. Warszawa: PWE.

19. OECD (2010). Regional Development Policies in OECD Countries, OECD Publishing.

20. OECD (2018). Green Growth Indicators 2017, OECD Publishing, www.oe.cd/ggi.

21. Pociecha, J., Podolec B., Sokolowski A., \& Zając, K. (1988). Metody taksonomiczne w badaniach spolecznoekonomicznych. PWN, Warszawa.

22. Stanimir, A. (2005). Analiza korespondencji jako narzedzie do badania zjawisk ekonomicznych. Wydaw. AE we Wroclawiu, Wroclaw.

23. WCED, World Commission on Environment and Development. (1987). Raport Brundtland. Our common future, Oxford, Oxford University Press, New York.

24.US, Urzad Statystyczny w Bialymstoku. (2017).Wskazniki zielonej gospodarki w Polsce w 2017. Bialystok.

25. Van de Rheede T. (2014). Report on the OECD Green Growth and Sustainable Development Forum 2014, OECD, Paris, France.

26.Ziolo, M., Fidanoski, F., Simeonovski, K., Filipovski, V. Jovanovska, K. (2016). Sustainable Finance. Role in Creating Conditions for Sustainable Economic Growth and Development. Springer International Publishing. 